University of Nebraska - Lincoln

DigitalCommons@University of Nebraska - Lincoln

Faculty Publications from the Harold W. Manter Laboratory of Parasitology

$6-2001$

\title{
Anindobothrium n. gen. (Eucestoda: Tetraphyllidea) Inhabiting Marine and Freshwater Potamotrygonid Stingrays
}

\author{
Fernando P.L. Marques \\ Universidade Estadual Paulist \\ Daniel R. Brooks \\ University of Toronto,dnlbrooks@gmail.com \\ Carlos A. Lasso \\ Museo de Historia Natural de La Salle
}

Follow this and additional works at: https://digitalcommons.unl.edu/parasitologyfacpubs

Part of the Parasitology Commons

\begin{abstract}
Marques, Fernando P.L.; Brooks, Daniel R.; and Lasso, Carlos A., "Anindobothrium n. gen. (Eucestoda: Tetraphyllidea) Inhabiting Marine and Freshwater Potamotrygonid Stingrays" (2001). Faculty Publications from the Harold W. Manter Laboratory of Parasitology. 258.

https://digitalcommons.unl.edu/parasitologyfacpubs/258

This Article is brought to you for free and open access by the Parasitology, Harold W. Manter Laboratory of at DigitalCommons@University of Nebraska - Lincoln. It has been accepted for inclusion in Faculty Publications from the Harold W. Manter Laboratory of Parasitology by an authorized administrator of DigitalCommons@University of Nebraska - Lincoln.
\end{abstract}




\title{
ANINDOBOTHRIUM N. GEN. (EUCESTODA: TETRAPHYLLIDEA) INHABITING MARINE AND FRESHWATER POTAMOTRYGONID STINGRAYS
}

\author{
Fernando P. L. Marques ${ }^{\star}$, Daniel R. Brooks $†$, and Carlos A. Lasso $\ddagger$ \\ University of Toronto, Department of Zoology, 25 Harbord St., Toronto, Ontario, Canada M5S 3G5
}

\begin{abstract}
Anindobothrium n. gen. is proposed to accommodate Caulobothrium anacolum inhabiting Himantura schmardae from Colombia, and 2 new species, one inhabiting Potamotrygon orbigny in Brazil and the other inhabiting Paratrygon aereiba in Venezuela. Members of the new genus resemble members of Pararhinebothroides, Rhinebothroides, and Anthocephalum by having bothridia with poorly differentiated apical suckers and vasa deferentia expanded into external seminal vesicles. It further resembles Pararhinebothroides, Rhinebothroides, and Anthocephalum cairae by having vas deferens inserted near the poral rather than aporal end of the cirrus sac. The 3 species assigned to the new genus form an apparent monophyletic group, based on the possession of 3 putative synapomorphies: (1) genital pores in the anterior $1 / 4$ of the proglottid, a trait that is unusual, but not unique, among phyllobothriids; (2) anteroventral ovarian lobes converging to the center of the proglottid, a character not previously reported for phyllobothriids; and (3) ovarian lobes comprising a loose network of digitiform processes.
\end{abstract}

Most species of stingrays are marine, although some occasionally enter freshwater systems. Neotropical stingrays (Paratrygon Duméril, 1865; Plesiotrygon Rosa, Castello, and Thorson, 1987; and Potamotrygon Garman, 1913) are obligatory freshwater inhabitants exhibiting low tolerance to saline waters (Thorson, 1970; Thorson et al., 1978; Nishida, 1990). The phylogenetic affinity of this group of elasmobranchs with marine stingrays has generated debate. Brooks, Thorson, and Mayes (1981) noted that the parasites of potamotrygonids known at that time were most closely related to parasites inhabiting members of the marine genus Urobatis Garman, 1913. Subsequent studies have suggested that the helminth fauna of potamotrygonids has a complex origin, with various groups showing affinities to parasites inhabiting members of Urobatis, Dasyatis Rafinesque, 1810, Himantura Müller and Henle, 1837, and even sharks (Brooks, 1992, 1995; Brooks and Deardorff, 1988; Hoberg et al., 1998; Marques et al., 1995, 1996, 1997; Monks et al., 1996; Zamparo et al., 1999; Marques, 2000).

Lovejoy $(1996,1997)$ and McEachran et al. (1996) suggested that the amphi-American clade of Himantura schmardae (Werner, 1904) + Himantura pacifica (Beebe and Tee-Van, 1941) is the sister group of potamotrygonids, with Taeniura Müller and Henle, 1837 being the sister group of that clade. McEachran et al. (1996) included Taeniura and the amphi-American Himantura within Potamotrygonidae. Based on a total evidence study of 4 mitochondrial genes and 65 morphological characters, Marques (2000) suggested that whereas support for the clade of amphi-American Himantura + potamotrygonids was strong, the placement of Taeniura was ambiguous; consequently, his conception of the Potamotrygonidae includes the amphi-American Himantura and the neotropical freshwater rays.

To date, members of 2 genera of phyllobothriid cestodes have been reported in freshwater potamotrygonids: Rhinebothroides Mayes, Brooks, and Thorson, 1981 with 7 nominal species inhabiting exclusively freshwater potamotrygonids, and Rhinebothrium Linton, 1889, a genus comprised of species inhabiting

Received 30 November 1999; revised 28 July 2000 and 27 November 2000; accepted 5 December 2000.

* Present address: Universidade Estadual Paulista, Departamento de Zoologia, Botucatu, São Paulo, Brazil 18618-000.

$\dagger$ University of Toronto, Department of Zoology, Toronto, Ontario, Canada M5S 3G5.

$\ddagger$ Museo de Historia Natural de La Salle, Caracas, Venezuela. marine elasmobranchs, of which only a single species is known from freshwater potamotrygonids.

Brooks (1977) described Rhinebothrium magniphallum, Rhinebothrium tetralobatum, and Caulobothrium anacolum from H. schmardae from the Caribbean Sea, and Marques et al. (1996) described Rhinebothrium geminum in $H$. pacifica from the Pacific coast of Costa Rica. Rhinebothrium magniphallum and $R$. geminum appear to be closely related to each other, based on their shared possession of a distinctively large cirrus sac, presumably a synapomorphy, and similarities in other diagnostic features (bothridial loculi form, number of bothridial loculi, and number of testes). Rhinebothrium tetralobatum is a member of a clade that includes Rhinebothrium paratrygoni Rêgo and Dias, 1979 inhabiting freshwater potamotrygonids, but it is not its sister species (see Brooks and Deardorff, 1988).

Caulobothrium anacolum has been an enigmatic species. Brooks (1977) assigned the species to Caulobothrium Baer, 1948, because it exhibited bothridia with transverse septa and no marginal loculi or apical suckers and possessed postvaginal testes, but they also noted a number of characters exhibited by the new species that were not reported in other members of the genus. The most recent diagnosis of the genus (Euzet, 1994) fails to include most species assigned to Caulobothrium, which appear to represent at least 2 different lineages, one characterized by bothridia having transverse septa only, compact ovaries, and a relatively small number of testes, including some that are postovarian; the other lineage is characterized by bothridia with transverse septa and a medial longitudinal septum, digitiform ovaries, and a relatively large number of testes, none of which is postovarian (Brooks, Mayes, and Thorson, 1981).

No putative close relative of Rhinebothroides is known to inhabit $H$. schmardae, $H$. pacifica, or Taeniura spp. The most recent phylogenetic analysis of Rhinebothroides and relatives suggests that the genus is the sister group of Pararhinebothroides hobergi Zamparo, Brooks, and Barriga, 1999, based on their shared possession of the vas deferens inserting into the cirrus sac near the poral end, rather than at the aporal end, a feature unique among tetraphyllideans (Zamparo et al., 1999). Pararhinebothroides hobergi inhabits Urobatis tumbesensis McEachran and Chirichigno in southern Ecuador. The sister group of Pararhinebothroides + Rhinebothroides is the paraphyletic Anthocephalum Linton, 1890 that includes species inhabiting stingrays of various genera (Ruhnke, 1994). 
TABLE I. List of the hosts examined from the Museo de Historia Natural La Salle (MHNLS), Caracas, Venezuela.

\begin{tabular}{cc}
\hline \multicolumn{1}{c}{ Species } & Locality (material collected) \\
\hline $\begin{array}{c}\text { Paratrygon aierei- } \\
\text { ba }\end{array}$ & Caño Guaritico, Hato el Frío, Orinoco Basin, \\
& Apure, Venezuela (4 specimens [MHNLS \\
Potamotrygon or- & Caño Guaritico, Hato el Frío, Orinoco Basin, \\
bignyi & Apure, Venezuela (1 specimen [MHNLS \\
& 6188]); Caño Macanillal, Hato el Frío, Orinoco \\
& Basin, Apure, Venezuela (2 specimens \\
& [MHNLS 6001, 6199]); Caño Magaletal, Hato \\
& La Ballera, Orinoco Basin, Apure, Venezuela \\
& (1 specimen [MHNLS 6208]). \\
Caño Guaritico, Hato el Frío, Orinoco Basin, \\
Apure, Venezuela (15 specimens [MHNLS \\
6187, 6189-6193, 6191, 6192, 6198, 6200- \\
6204, 6209]); Caño Magaletal, Hato La Bal- \\
lera, Orinoco Basin, Apure, Venezuela (1 spec- \\
imen [MHNLS 6209]).
\end{tabular}

The present study describes 2 new species of phyllobothriids inhabiting potamotrygonids, all of which exhibit external seminal vesicle insertions near the poral end of the cirrus sac. Reexamination of $C$. anacolum revealed that it also exhibits this trait. To accommodate these findings taxonomically, we propose a new genus to receive $C$. anacolum and 2 new species of phyllobothriids inhabiting freshwater potamotrygonids.

\section{MATERIALS AND METHODS}

Freshwater potamotrygonids were collected using long-lines from the Amazon and northeastern Brazil during September-December 1996 (see Marques [2000] for the list of hosts and localities). Cestodes were removed from the spiral valve, placed in freshwater, and fixed with hot alcohol-formalin-acetic acid for $24 \mathrm{hr}$ prior to transfer to $70 \%$ ethanol for storage. The spiral valve was fixed in warm solution of $10 \%$ formalin for later examination. Additional cestodes were obtained from hosts collected in the Orinoco drainage in Venezuela, during October 1991 and August 1997 (Table I) and fixed with 10\% formalin. Spiral valves from these hosts were removed and examined for parasites in the laboratory.

Whole mounts of cestodes were stained with acetocarmine or Mayer's hematoxylin, dehydrated in ethanol, cleared in methyl salycilate, and mounted in Canada balsam. Serial transverse sections of specimens in paraffin were cut at $8-\mu \mathrm{m}$ intervals and stained with hematoxylin and eosin. Measurements were obtained using an Optimas image analysis system. Measurements include the range, followed by the mean, standard deviation, and sample size in parentheses. For measurements of 2 specimens, only the range is provided. All measurements are in $\mu \mathrm{m}$ unless otherwise stated. Figures were drawn with the aid of a drawing tube. Specimens prepared for scanning electronic microscopy were postfixed in $1 \%$ osmium tetroxide, infiltrated, and dried with Peldri II (Ted Pella Inc., Redding, California), mounted on stubs with contact adhesive tape, and sputter coated with gold. Type specimens and vouchers were deposited in the Coleção Helmintológica do Instituto Oswaldo Cruz (CHIOC), Rio de Janeiro, Brazil; Instituto Nacional de Pesquisa da Amazônia (INPA), Manaus, Brazil; U.S. National Parasite Collection (USNPC), Beltsville, Maryland; Museo de Historia Natural La Salle (MHNLS), Caracas, Venezuela; and Harold W. Manter Laboratory (HWML), University of Nebraska, Lincoln, Nebraska.

\section{DESCRIPTION}

\section{Anindobothrium n. gen.}

Diagnosis: Phyllobothriidae. Scolex with 4 sessile or pedicellated quadrate, bilobed bothridia; each lacking longitudinal septa, bearing transverse loculi and poorly differentiated apical suckers; marginal loculi present or absent. Genital pores marginal, in anterior $1 / 4$ of proglottid, irregularly alternating. Testes numerous. Vas deferens expanded to form distinct seminal vesicle joining cirrus sac more porally than aporally; internal seminal vesicle present or absent. Cirrus sac with armed cirrus. Ovary near posterior end of proglottid, X-shaped in cross section; arms symmetrical. Vagina anterior to cirrus sac; vaginal sphincter present. Vitelline follicles lateral. Uterus saccate, with poorly differentiated lateral diverticula or lacking diverticula. Parasites in spiral valve of stingrays.

\section{Taxonomic summary}

Type species: Anindobothrium anacolum (Brooks, 1977) n. comb. Etymology: The genus is named in honor of Dr. Anindo Choudhury.

Anindobothrium anacolum (Brooks, 1977) n. comb. (Fig. $1 A-C)$

Synonym: Caulobothrium anacolum Brooks, 1977.

Diagnosis (modified from Brooks, 1977): Strobila acraspedote, apolytic, 6.8-15.4 mm long, composed of 13-32 proglottids. Scolex with 4 pedicellated, quadrate, bilobed bothridia bearing 22-23 transverse septa disjunct in center of bothridium forming 42-44 loculi; marginal loculi and longitudinal septum absent. Testes in anterior $3 / 4$ of proglottid, 34-45 in number. Vas deferens expanded to form distinct seminal vesicle joining cirrus sac more porally than aporally; internal seminal vesicle absent. Genital pore $19-29 \%$ of the proglottid length from anterior end, irregularly alternating. Vitelline ducts unequal in length, joining laterally at ovarian lobe.

\section{Taxonomic summary}

Host: Himantura schmardae (Werner) (Myliobatoidei: Potamotrygonidae).

Site: Spiral valve.

Locality: Caribbean Sea, $15 \mathrm{~km}$, west of La Cienaga, Magdalena, Colombia $\left(11^{\circ} 01^{\prime} \mathrm{N}, 074^{\circ} 15^{\prime} \mathrm{W}\right)$.

Holotype: USNPC 73969.

Paratypes: USNPC 73970, HWML 20265.

\section{Anindobothrium lisae $\mathrm{n} . \mathbf{s p}$.} (Fig. 2A-D)

Description (based on 27 mature, 9 incomplete, and 5 immature specimens): Strobila acraspedote, apolytic. Mature worms 3.7-14.7 (8.94 \pm $3.2,21)$ long, composed of 7-28 $(16 \pm 5,27)$ proglottids; immature worms $2.1-9(3.8 \pm 2.9,5)$ long, composed of 3-16 $(10 \pm 6,5)$ proglottids. Scolex 342-960 (529 $\pm 165, \mathrm{n}=25)$ long by $573-1,218$ ( 890 $\pm 203,26)$ wide in mature specimens, $344-793(511 \pm 166, \mathrm{n}=6)$ long by $460-993(748 \pm 213,8)$ wide in immature worms, with 4 quadrate, bilobed bothridia. Bothridial pedicels ranging from inconspicuous up to $150-350(254 \pm 66,9)$ long according to maturity. Bothridia $377-923(601 \pm 158,13)$ long by $322-775(595 \pm 156,10)$ wide in mature worms, $399-816(536 \pm 138,7)$ long by $435-497(475 \pm 28$, 4) wide in immature worms, bearing 51-69 $(61 \pm 7,6)$ marginal loculi in mature worms, 55-57 $(56 \pm 1,6)$ in immature worms; transverse and longitudinal septa absent. Anterior sucker $45-80(64 \pm 10,14)$ in diameter in mature worms, 48-72 $(62 \pm 9,6)$ in immature worms. Immature proglottids $358-1,112(775 \pm 238,12)$ long by $282-504(400$ $\pm 72,12)$ wide; mature proglottids $631-2,348(1,293 \pm 383,84)$ long by $296-790(456 \pm 90,86)$ wide. Testes in anterior $3 / 4$ of proglottid, $32-118(74 \pm 15,165)$ long by $22-104(52 \pm 19,163)$ wide; 38-74 $(54 \pm 8,48)$ in number; $5-13(8 \pm 2,48)$ preporally, $10-26(17 \pm 4$, $48)$ postporally, 21-38 (29 $\pm 4,48)$ aporally. Vas deferens expanded to form distinct seminal vesicle joining cirrus sac more porally than aporally; internal seminal vesicle present. Cirrus sac in anterior $1 / 4$ of the proglottid, $103-319(152 \pm 32,67)$ long by $44-229(86 \pm 28,67)$ wide in mature specimens, contained spined eversible cirrus. Genital atrium inconspicuous. Genital pore $54-92 \%(74 \pm 6 \%, 70)$ of the proglottid length from posterior end, irregularly alternating. Vagina anterior to cirrus sac, vaginal sphincter inconspicuous, posterior portion expanded to form seminal receptacle. Ovary bilobed in frontal view, $\mathrm{X}$-shaped in cross-section, follicular, poral lobes $132-482(230 \pm 77,66)$ long, apor- 

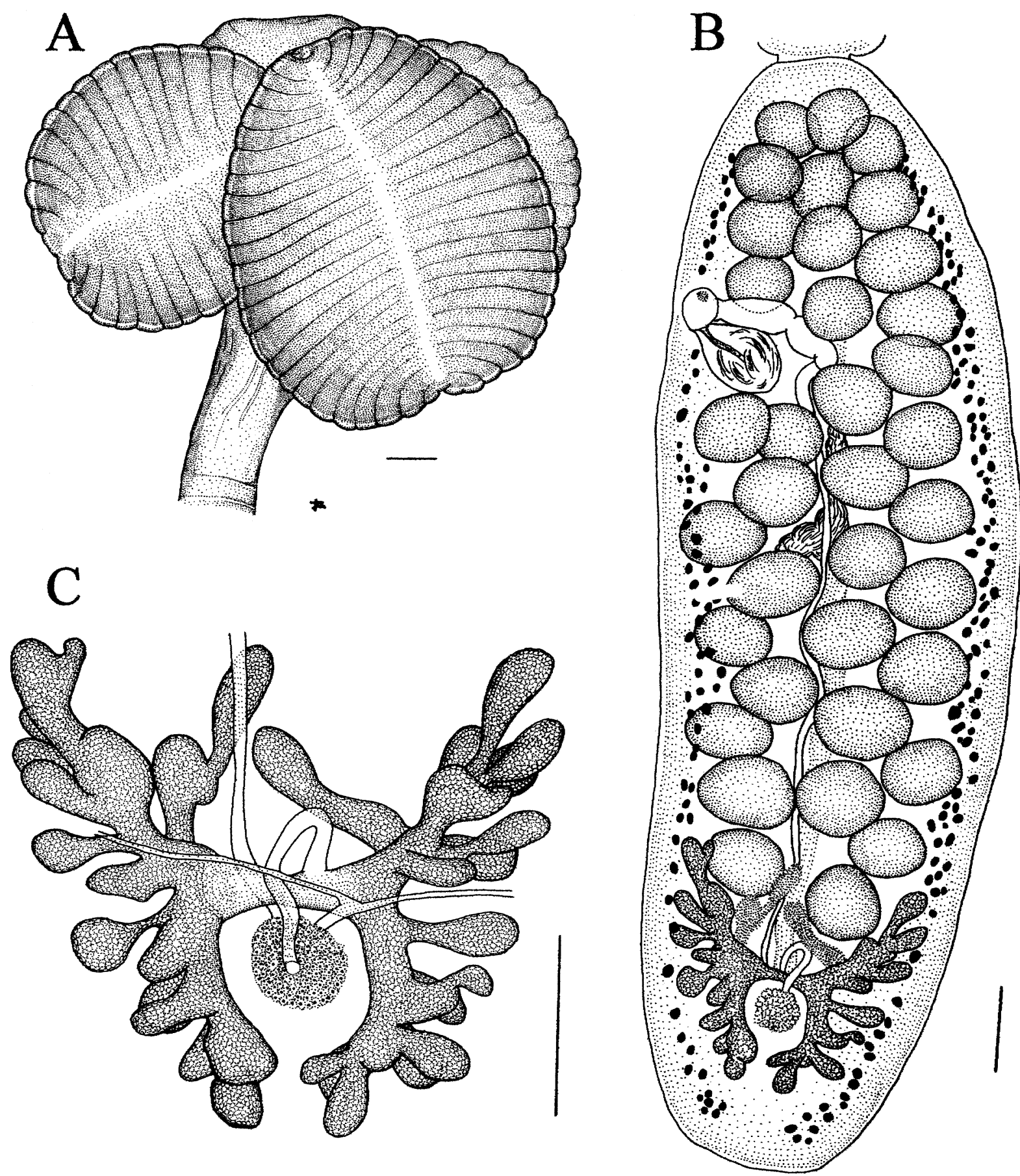

FIGURE 1. Anindobothrium anacolum n. comb. A. Scolex (USNPC 73969, holotype). B. Mature segment (USNPC 73970, paratype). C. Ovary (USNPC 73970, paratype). Scale bar $=100 \mu \mathrm{m}$.

al lobes $117-453(231 \pm 78,66)$. Ovary $135-360(233 \pm 49,64)$ wide at isthmus in mature proglottids; anteroventral lobes converging anteriorly to midline of proglottid, but not fused. Vitelline follicles extending length of proglottid, 9-49 $(27 \pm 9,152)$ long by $8-35(17 \pm 5$, 152) wide. Vitelline ducts unequal in length, joining laterally at ovarian lobe.

\section{Taxonomic summary}

Host: Potamotrygon orbignyi (Castelnau) (Myliobatoidei: Potamotrygonidae).

Site: Spiral valve.
Locality: Rio Negro near Barcelos, Amazonas, Brazil $\left(00^{\circ} 59^{\prime} \mathrm{S}\right.$, $\left.062^{\circ} 58^{\prime} \mathrm{W}\right)$.

Holotype: CHIOC 34375

Paratypes: INPA 0400ab, USNPC 91227-9, HWML 16379.

Etymology: This species is named for Lisa M. Nodwell.

\section{Anindobothrium guariticus n. sp.}

(Fig. 3A, B)

Description (based on 4 complete specimens): Strobila acraspedote, apolytic; mature worms ranging from 20 to $54 \mathrm{~mm}$ in length, composed of $68-126$ proglottids. Scolex $550-611$ long by $768-788$ wide, with 4 


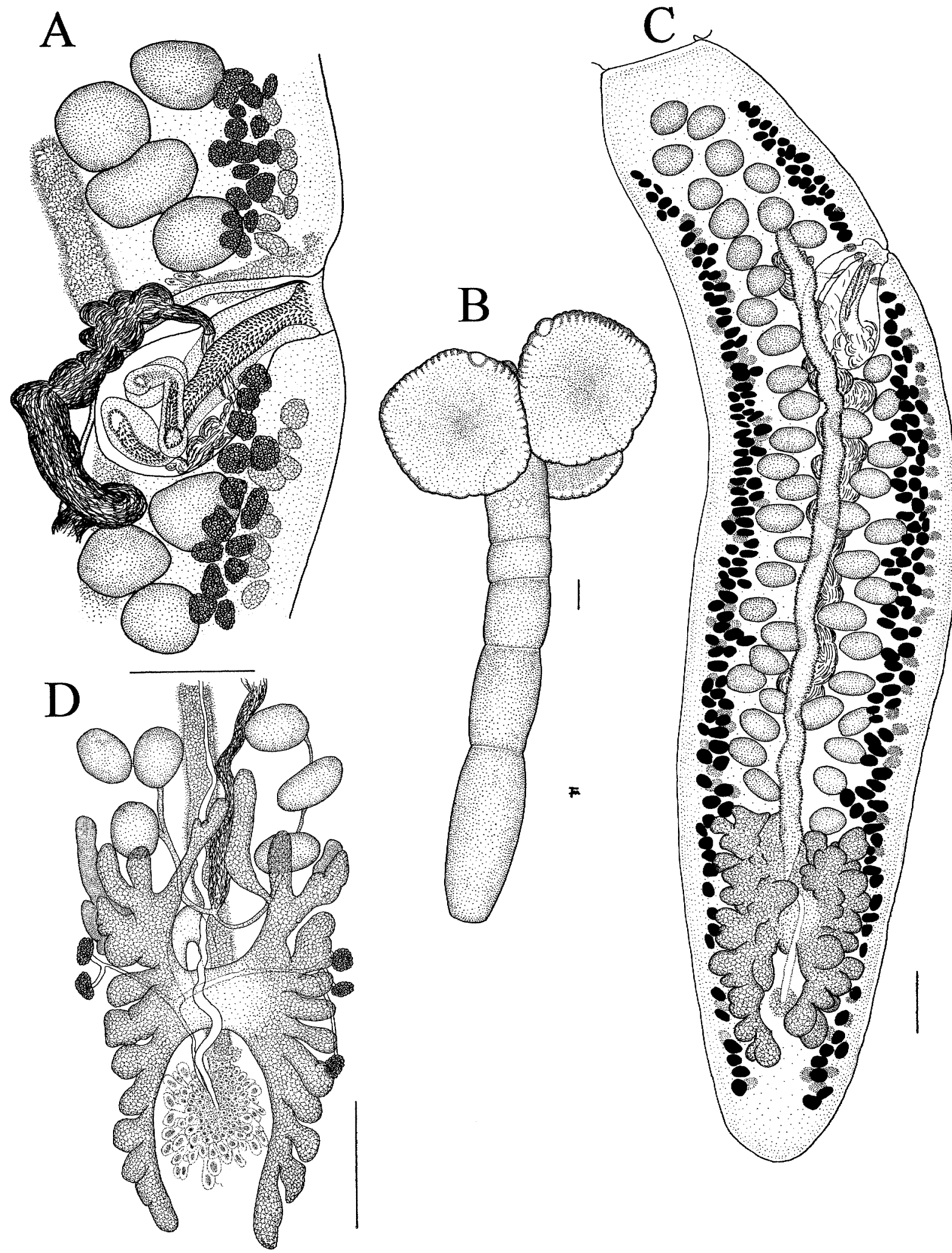

Figure 2. Anindobothrium lisae n. sp. A. Cirrus sac region. B. Immature specimen. C. Mature terminal segment. D. Ovary region. Scale bars $=100 \mu \mathrm{m}$ 

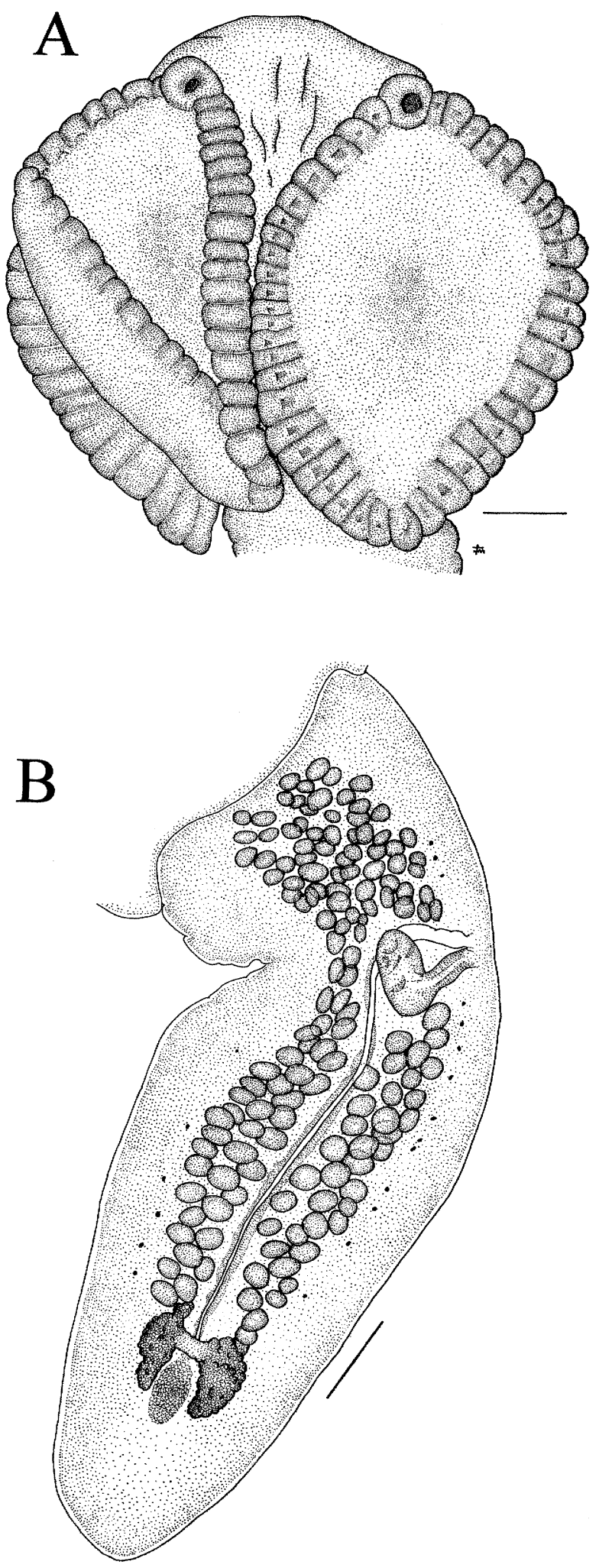

FIGURE 3. Anindobothrium guariticus n. sp. A. Scolex. B. Immature terminal segment. Scale bars $=100 \mu \mathrm{m}$. quadrate, bilobed bothridia bearing approximately 46 marginal loculi; transverse and longitudinal septa absent. Anterior sucker 70-73 in diameter. Cephalic peduncle 2,250-4,500 long. Immature proglottids wider than long, mature proglottids up to 951 long by 341 wide. Testes in anterior $3 / 4$ of the segment, $24-79(45 \pm 17,15)$ long by $16-55(31 \pm$ $12,15)$ wide; $141-161$ in number; $40-41$ preporally, 38 postporally, 63-82 aporally. Vas deferens expanded to form distinct seminal vesicle joining cirrus sac more porally than aporally. Cirrus sac in anterior $1 / 4$ of the proglottid, 158-198 long by 47-127 wide, containing spined eversible cirrus. Genital atrium inconspicuous. Genital pore $75 \%$ of proglottid length from posterior end, irregularly alternating. Vagina anterior to cirrus sac, vaginal sphincter not observed, posterior portion expanded to form seminal receptacle. Ovary bilobed in frontal view, $\mathrm{X}$-shaped in cross-section, follicular. Ovarian poral lobe 95 long, aporal lobe 92 long, 95 wide at isthmus in mature proglottids. Anteroventral lobes converging anteriorly but not fused. Vitelline follicles extending length of proglottid, $16-20(17 \pm 2,5)$ long by $8-16(13 \pm 3,5)$ wide.

\section{Taxonomic summary}

Host: Paratrygon aiereiba (Müller and Henle) (Myliobatoidei: Potamotrygonidae). Hosts deposited at MHNLS under accession numbers 6205 and 6206.

Site: Spiral valve.

Locality: Caño Guaritico, Hato El Frío, Orinoco Basin, Venezuela $\left(07^{\circ} 52^{\prime} \mathrm{N}, 069^{\circ} 20^{\prime} \mathrm{W}\right)$.

Holotype: MHNLS 6215

Paratypes: USNPC 91230, MHNLS 6216

Etymology: This species was named after its type locality, Caño Guaritico.

\section{Remarks}

Members of the new genus resemble species of Pararhinebothroides, Rhinebothroides, and Anthocephalum by having bothridia with poorly differentiated apical suckers and vasa deferentia expanded into external seminal vesicles. In particular, they further resemble members of Pararhinebothroides and Rhinebothroides, as well as Anthocephalum cairae Ruhnke, 1994 by having the vas deferens inserted near the poral rather than aporal end of the cirrus sac. However, distinctive differences in scolex morphology have traditionally been the basis for designating higher taxa among eucestodes and can be used to distinguish these groups. Rhinebothroides spp. possess marginal loculi, transverse septa, and a median longitudinal septum on each bothridium. Pararhinebothroides, as well as members of Anthocephalum and Phyllobothrium kingae Schmidt, 1978, possess marginal loculi that appears to be a basal synapomorphy for the entire group (Zamparo et al., 1999). Anindobothrium anacolum $\mathrm{n}$. comb. possesses transverse septa and lacks marginal loculi, whereas A. lisae n. sp. and A. guariticus n. sp. possess marginal loculi and lack transverse septa.

Within Anindobothrium n. gen., the specimens of A. guariticus n. sp. available for this study were poorly preserved because they were collected from hosts that had been fixed prior to necropsy. Thus, some meristic characteristics of this new species should be interpreted with caution, e.g., strobilar and proglottid lengths, and should be re-evaluated after further collection of properly fixed specimens. Likewise, a more detailed description of ovary and cirrus sac is required. However, $A$. guariticus $\mathrm{n}$. sp. is clearly a distinct and recognizable species. Compared to A. lisae n. sp., A. guariticus n. sp. is a robust cestode, differing from A. lisae n. sp. by having greater number of proglottids (68-126 vs. 728 ) and number of testes (141-161 vs. 38-74). In this regard, $A$. anacolum more closely resembles $A$. lisae.

\section{DISCUSSION}

The taxonomy of phyllobothriids has long puzzled parasitologists (see Runhke, 1994), because many of the higher taxonomic groups are not defined on the basis of unique characters, but instead are based on a combination of nonunique features. Also, because phyllobothriids show great morphological diversity and are relatively poorly known, many higher level taxonomic diagnoses have been emended to accommodate new taxa 
to the point that these diagnoses could be applied to many taxonomic entities. A classic example is Phyllobothrium van Beneden, 1849. From its original conception by van Beneden (1849), to workers who proposed much broader concepts of Phyllobothrium (e.g., Southwell, 1925; Yamaguti, 1959; Schmidt, 1986; Euzet, 1994), the generic diagnosis became so generalized that it could be applied to virtually all nonhooked, bothridium-bearing tetraphyllideans (Runhke, 1996).

Consistent application of a single systematic principle will improve the taxonomy of phyllobothriids. All higher taxa proposed should be diagnosed by at least 1 apomorphic trait, the quality of which should be highly general. This is especially true when one is proposing a monotypic higher taxon, because we expect higher taxa to include more than 1 species. In the present study, simply designating apomorphic traits for new species could have permitted us to designate 2 genera, 1 monotypic (for A. anacolum) and 1 comprising 2 species (for A. lisae and $A$. guariticus).

Diagnosis based on apomorphies will always produce more stable taxonomic structures than those based on overall similarity that may include plesiomorphies and homoplasies. An example within phyllobothriids is the resurrection of Anthocephalum Linton, 1890 by Ruhnke (1994). The genus had been considered to be a junior synonym of Phyllobothrium, but Ruhnke (1994) considered Anthocephalum a coherent phenetic group and resurrected the genus. Zamparo et al. (1999), however, found that this coherent phenetic group was paraphyletic if Pararhinebothroides and Rhinebothroides were excluded from it. By contrast, the 3 species assigned to Anindobothrium n. gen. form an apparent monophyletic group, based on their shared possession of 3 putative synapomorphies: (1) genital pores in the anterior $1 / 4$ of the proglottid, a trait that is unusual but not unique among phyllobothriids; (2) anteroventral ovarian lobes converging to the center of the proglottid, a character not previously reported for phyllobothriids; and (3) ovarian lobes comprising a loose network of digitiform processes.

Finally, if those tetraphyllideans possessing external seminal vesicles inserted into the cirrus sac porally represent a clade, the present study suggests that a new phylogenetic assessment of the position of $P$. hobergi and A. cairae within the larger group may be necessary. Anthocephalum alicae Ruhnke, 1994, A. cairae, Anthocephalum centrurum (Southwell, 1925), and $P$. hobergi exhibit ovarian lobes that expand laterally to such an extent in mature proglottids that the vitelline follicles are interrupted at the ovarian level. This trait is not found in basal members of Anthocephalum, in Anindobothrium spp., or in Rhinebothroides spp. (see Ruhnke, 1994; Zamparo et al., 1999). In the analysis by Zamparo et al. (1999), the vitelline distribution exhibited by Rhinebothroides spp. was considered to be a consequence of the modification of the ovarian shape in Rhinebothroides, producing a reversal in vitelline structure. It is possible, however, that the condition exhibited by $P$. hobergi and some members of Anthocephalum is a synapomorphy for those species. If so, the anterior insertion of the external seminal vesicle in A. cairae, Pararhinebothroides, Rhinebothroides, and Anindobothrium may be homoplasious.

\section{ACKNOWLEDGMENTS}

We thank Lisa Nodwell, Jaime Carvalho Jr., Maria L. G. Araújo, Labbish Chao, and the staff and students of the Projeto Piaba, Barcelos,
Amazonas, Brazil, for their assistance during the field work in the Amazon region. We are grateful for the hospitality of Maura Kumagay and her family to F.P.L.M. during his stay in Belém do Pará. This work could not be realized without the help of local fishermen from the Amazon region to whom we express our gratitude. We thank Scott Monks and Anindo Choudhury for reviewing early versions of this manuscript. We are also thankful to Gerhard Pohle, Atlantic Reference Centre, St. Andrews, New Brunswick, Canada, for allowing us to use his image analysis software. This work was financially supported by CNPq (Consenho Nacional de Desenvolvimento Científico e Tecnológico, Federal Government of Brazil) doctoral fellowship to F.P.L.M. and an NSERC (Natural Sciences and Engineering Council of Canada) operating grant A7696 to D.R.B.

\section{LITERATURE CITED}

BENEDEN, P. J. VAN. 1849. Les helminthes cestoides, considérés sous le rapport de leurs métamorphoses, de leur composition anatomique et de leur classification et mention de quelques spéces nouvelles de nos poissons plagiostomes. Bulletin de l'Académie Royal des Sciences, des Lettres et des Beaoux-Arts de Belgique 16: 269-282.

BrooKs, D. R. 1977. Six new species of tetraphyllydean cestodes, including a new genus, from a marine stingray Himantura schmardae (Werner, 1904) from Colombia. Proceedings of the Helminthological Society of Washington 44: 51-59.

- 1992. Origins and diversification of Neotropical freshwater stingrays (Potamotrygonidae): Parasitological evidence. Journal of Parasitology 78: 588-595.

- 1995. Neotropical freshwater stingrays and their parasites: A tale of an ocean and a river long ago. Journal of Aquariculture and Aquatic Science 7: 52-61.

- , AND T. L. DEARDORFF. 1988. Rhinebothrium devaneyi n. sp. (Eucestoda: Tetraphyllidea) and Echinocephalus overstreeti Deardorff and Ko, 1983 (Nematoda: Gnathostomatidae) in a thorny back ray, Urogymnus asperrimus, from Enewetak Atoll, with phylogenetic analysis of both species groups. Journal of Parasitology 74: 459-465.

- M. A. MAyes, AND T. B. Thorson. 1981. Cestode parasites in Myliobatis goodei Garman (Myliobatiformes: Myliobatidae) from Rio de la Plata, Uruguay with a summary of cestodes collected from South American elasmobranchs during 1975-79. Proceedings of the Biological Society of Washington, D.C. 93: 1239-1252.

, T. B. ThORSON, AND M. A. MAYES. 1981. Freshwater stingrays (Potamotrygonidae) and their helminth parasites: Testing hypothesis of evolution and coevolution. In Advances in cladistics, V. A. Funk and D. R. Brooks (eds.). New York Botanical Garden, New York, New York, p. 147-175.

EuzET, L. 1994. Tetraphyllidea. In Keys to the cestode parasites of vertebrates, L. F. Khalil, A. Jones, and R. A. Bray (eds.). CAB International, Cambridge, U.K., p. 149-194.

Hoberg, E. P., D. R. Brooks, H. Molina-Urena, and E. Erbe. 1998. Echinocephalus janzeni n. sp. (Nematoda: Gnathostomidae) in Himatura pacifica (Chondrichthyes: Myliobatiformes) from the $\mathrm{Pa}$ cific coast of Costa Rica and Mexico, with historical biogeographic analysis of the genus. Journal of Parasitology 84: 571-581.

LOVEJOY, N. R. 1996. Systematics of myliobatoid elasmobranchs: With emphasis on the phylogeny and historical biogeography of neotropical freshwater stingrays (Potamotrygonidae: Rajiformes). Zoological Journal of the Linnean Society 117: 207-257.

. 1997. Stingrays, parasites, and neotropical biogeography: A closer look at Brooks et al.'s hypothesis concerning the origins of neotropical freshwater rays (Potamotrygonidae). Systematic Biology 46: 218-230.

MARQUES, F. 2000. Evolution of Neotropical freshwater stingrays and their parasites: Taking into account space and time. Ph.D. Dissertation. University of Toronto, Toronto, Ontario, Canada, 322 p.

$-\longrightarrow$, AND R. BARRIGA. 1997. Six species of Acanthobothrium (Eucestoda: Tetraphyllidea) in stingrays (Chondrichthyes: Rajiformes: Myliobatoidei) from Ecuador. Journal of Parasitology 84: 475-484.

, AND S. MONKS. 1995. Five new species of Acanthobothrium van Beneden, 1849 (Eucestoda: Tetraphyllidea: Oncho- 
bothriidae) in stingrays from the Gulf of Nicoya, Costa Rica. Journal of Parasitology 81: 942-951.

, phyllidean cestodes in Himantura pacifica (Chondrichthyes: Myliobatiformes: Dasyatidae). Journal of Parasitology 82: 302-306.

McEachran, J. D., K. A. Dunn, and T. MiYaKe. 1996. Interrelationships of the batoid fishes (Chondrichthes: Batoidea). In Interrelationships of fishes, M. L. J. Stissiany, L. R. Parenti, and G. D. Johnson (eds.). Academic Press, New York, New York, p. 63-84.

Monks, S., D. R. Brooks, ANd G. Pérez PonCE de León. 1996. A new species of Acanthobothrium Van Beneden, 1849 (Eucestoda: Tetraphyllidea: Onchobothriidae) in Dasyatis longus Garman (Chondrichthyes: Myliobatiformes: Dasyatididae) from Chamela Bay, Jalisco, Mexico. Journal of Parasitology 82: 484-488.

NisHIDA, K. 1990. Phylogeny of the superorder Myliobatoidei. Memoir of the Faculty of Fisheries, Hokkaido University 37: 1-108.

RunHKe, T. R. 1994. Resurrection of Anthocephalum Linton, 1890 (Cestoda: Tetraphyllidea) and taxonomic information on five proposed members. Systematic Parasitology 29: 159-176.
1996. Taxonomic resolution of Phyllobothrium van Beneden (Cestoda: Tetraphyllidea) and a description of a new species from the leopard shark Triakis semifasciata. Systematic Parasitology 33: $1-12$.

SCHMIDT, G. D. 1986. CRC handbook of tapeworm identification. CRC Press Inc., Boca Raton, Florida, 675 p.

Southwell, T. 1925. A monograph on Tetraphyllidea. Memoirs of the Liverpool School of Tropical Medicine (New Series) 2: 1-368.

Thorson, T. B. 1970. Freshwater stingrays, Potamotrygon spp.: Failure to concentrate urea when exposed to saline medium. Life Sciences 9: $893-900$.

, R. M. Wooton, AND T. D. Georgi. 1978. Rectal gland of freshwater stingrays, Potamotrygon spp. (Chondrichthyes: Potamotrygonidae). Biological Bulletin 154: 508-516.

YAMAGUTI, S. 1959. Systema helminthum, Vol. 2. The cestodes of vertebrates. Interscience Publishers Limited, London, U.K., 860 p.

ZAMPARO, D., D. R. BROOKS, AND R. BARRIGA. 1999. Pararhinebothroides hobergi $\mathrm{n}$. gen., $\mathrm{n}$. sp. (Eucestoda: Tetraphyllidea) in Urobatis tumbesensis (Chondrichthyes: Myliobatiformes) from Coastal Ecuador. Journal of Parasitology 85: 534-539. 